\title{
Production and analysis of tomato Solanum lycopersicum composite plants carrying the genes of pea Pisum sativum receptors to rhizobial signaling molecules Rudaya E.S., Dolgikh E.A.
}

All-Russian Research Institute for Agricultural Microbiology, Saint Petersburg, Russia

E-mail: rudaya.s.e@gmail.com

Key message. The interaction of composite tomato plants carrying constructs with pea genes encoding receptors to Nod factors, with nitrogen-fixing bacteria rhizobia was investigated.

Keywords: legume-rhizobial symbiosis, receptor-like kinases, Nod factors, composite tomato plants

The ability to fix atmospheric nitrogen by non-legume plants reveals new perspectives for the establishment of an effective farming without using of chemical fertilizers. The most important in this process may be the possibility of acquiring by nonlegume plants the capability to perceive the signal molecules of nitrogen-fixing bacteria rhizobia and transduce the signal, that important for mutual recognition of partners. Thereby, the aim of this work was to study the influence of genes of legume plant pea of Pisum sativum L., encoding receptors to signal molecules Nod factors and the main regulators of signaling pathway, on the ability of transgenic and composite plants of Solanum lycopersicum tomato cv. Carmello to interact with rhizobia.

Composite plants containing the genetic constructs with sequences of genes encoding pea receptors SYM10 and K1, as well as the transcription factor NIN, under control of the constitutive promoter pCaMV35S and tissue-specific promoter pSIEXT1 of tomato extensin gene were obtained using agrobacterial transformation with Agrobacterium rhizogenes. The efficiency of the distribution of rhizobia in the plants root tissues was checked in 21 day after inoculation with the labelled Rhizobium leguminosarum CIAM1026 strain. The efficiency of gene transfer after transformation was verified by PCR analysis using as matrix the DNA and mRNA isolated from tomato transgenic roots, in 1 and 3 weeks after inoculation. In transgenic roots the expression of the PsSym10 and PsK1 genes cloned under the pSlEXT1 promoter was increased in 1 week after inoculation compared with the control transgenic tomato roots without inoculation. Stimulation of the PsSymlO and PsK1 gene expression may be connected with rhizobial inoculation, while the $p S I E X T 1$ promoter is activated by ethylene.

The work was supported by RSF16-16-10043

\section{Получение и анализ композитных растений томатов Solanum lycopersicum, несущих гены рецепторов гороха Pisum sativum к сигнальным молекулам ризобий \\ Рудая Е.С., Долгих Е.А. \\ ВНИИ сельскохозяйственной микробиологии, Санкт-Петербург, Пушкин, Росссия}

\begin{abstract}
Аннотация. В работе было изучено взаимодействие композитных растений томата, несущих конструкции с генами, кодирующими рецепторы гороха к Nod-факторам, с азотфиксирующими бактериями ризобиями.

Ключевые слова: бобово-ризобиальный симбиоз, рецептор-подобные киназы, Nod-факторы, композитные растения томата
\end{abstract}

Способность к фиксации атмосферного азота у небобовых растений открывает новые перспективы в становлении эффективного земледелия без использования химических удобрений. Важным в этом процессе является возможность приобретения небобовыми растениями способности к рецепции сигнальных молекул азотфиксирующих бактерий ризобий и дальнейшей передаче сигнала, что лежит в основе узнавания партнеров. В связи с этим, целью данной работы стало изучение влияния генов бобового растения гороха Pisum sativum L., кодирующих рецепторы к сигнальным молекулам Nod-факторам и основные регуляторы сигнального пути, на способность трансгенных и композитных растений томата Solanum lycopersicum cv. Carmello взаимодействовать с ризобиями.

Методом агробактериальной трансформации с помощью Agrobacterium rhizogenes были получены композитные растения, содержащие генетические конструкции с последовательностями генов, кодирующих рецепторы гороха SYM10 и K1, а также транскрипционный фактор NIN, под конститутивным промотором pCaMV35S и тканеспецифичным промотором pSIEXT1 гена экстенсина томата. Через 21 день после инокуляции меченным штаммом $R$. leguminosarum CIAM1026 у растений проверяли эффективность распространения ризобий в тканях корня. Эффективность переноса генов после трансформации проверяли посредством ПЦР-анализа на матрице ДНК и мРНК, выделенных из трансгенных корней томата, через 1 и 3 недели после инокуляции. В трансгенных корнях томата экспрессия генов PsSym10 и PsK1, клонированных под промотором pSlEXT1, на 1 неделе после инокуляции оказалась выше, чем в контроле без инокуляции. Стимуляция экспрессии генов PsSym10 и PsK1, может быть ответом на инокуляцию ризобиями, поскольку промотор активируется в ответ на этилен.

Работа была поддержана грантом РНФ16-16-10043. 